\title{
Reducing Department Chair Stress Through Effective Allocation Of Travel Funds
}

Ronald Mano, (Email: rmano@weber.edu), Weber State University

I became Department Chair on July 1, 1998. Since that time, our travel funds have increased as follows:

\begin{tabular}{|c|c|}
\hline $1997-1998$ & $\$ 11,000$ \\
\hline $1998-1999$ & $\$ 14,000$ \\
\hline $1999-2000$ & $\$ 28,380$ \\
\hline $2000-2001$ & $\$ 40,580$ \\
\hline $2001-2002$ & $\$ 50,580$ \\
\hline $2002-2003$ & $\$ 58,080$ \\
\hline $2003-2004$ & $\$ 58,080$ \\
\hline $2004-2005$ & $\$ 62,080$ \\
\hline
\end{tabular}

During this time period, our faculty size has remained constant at eleven.

There are several factors that have allowed us to accomplish this increase in travel funds. The most important seems to be control of the department budget, second seems to be increased outside fund raising, and thirdly are some additional funds that have come because of differential tuition now being charged to graduate students.

During this same period, our gift account (or "slush" fund) has increased significantly. The following table illustrates that increase.

\begin{tabular}{|c|c|}
\hline July 1,1998 & $\$ 1,768.05$ \\
\hline July 1,1999 & $\$ 20,011.65$ \\
\hline July 1,2000 & $\$ 35,006.68$ \\
\hline July 1,2001 & $\$ 55,418.47$ \\
\hline July 1,2002 & $\$ 97,830.20$ \\
\hline July 1,2003 & $\$ 118,305.78$ \\
\hline July 1,2004 & $\$ 133,976.96$ \\
\hline
\end{tabular}

The composition of the $\$ 133,976.96$ balance at July 1, 2004 is as follows:

\begin{tabular}{|c|c|}
\hline Interest & $\$ 13,890.00$ \\
\hline Contributions & $\$ 29,820.94$ \\
\hline Operating Funds & $\$ 90,266.02$ \\
\hline TOTAL & $\mathbf{\$ 1 3 3 , 9 7 6 . 9 6}$ \\
\hline
\end{tabular}

\section{CONTROL OF THE DEPARTMENT BUDGET}

I have to believe that a major reason we have been able to accomplish the above record is because of an emphasis on control of the Department budget. I do not know why we were not able to do essentially the same thing in prior years because our budget has not significantly increased during these years except in 2001-2002. That increase is the differential graduate tuition that was mentioned above and will be explained in more detail below. 
I believe that I am first and foremost an accountant and secondarily an academic. I love being an accountant. Therefore, when I became chair, I immediately began doing accountant type things. I needed to know about the Department budget, how much we had and what it was used for.

\section{SCHOLARSHIP DEFICIT}

I went to inquire of the Dean about the budget accounts over which I had responsibility. He said, "Well you have this one which has a deficit of $\$ 3,488.74$ in it." It was a scholarship account. I asked him what had happened and he said that he did not know. I then solicited the assistance of the prior Department chair who was still a member of our faculty. With her help and lots of hours of accounting (audit) work on my part, we determined that the problem went back to 1993 and had never been resolved in all of that time. Back then we had awarded scholarships but never received the funds from the donors. Recall that I became Department chair on July 1, 1998. It took me several months to analyze the cause of this problem. At that point, I went to the Dean and begged that he solve the problem for me. I told him that he could not force me to begin my tenure as Department chair in a $\$ 3,500$ hole. He obliged and gave me the money to bring that account to a zero balance.

\section{TELEPHONE CHARGES}

After resolving the scholarship account problem, I began to analyze one of our largest department operating expenses, the telephone. We are charged a monthly charge for each telephone plus charges for all long-distance calls made by our faculty. As I reviewed those charges, I found that we were paying a monthly rental for two individuals who had left our faculty almost four years previously. We also had a phone in a storage room across the hall. I immediately had all three of those phones cancelled and immediately saved the department over $\$ 50$ per month.

Each month, I meticulously review all of the charges to our department. Almost monthly, I find charges which are erroneous and need to be corrected. Those which are not in our favor I get corrected immediately. Those which are in our favor, I do not have corrected for two reasons. They are in our favor, and I want to see how long it takes others to get things corrected; in other words, do others review their finances anywhere near as meticulously as I do.

It is interesting to note that as of December, 2000, the long-distance telephone charges for two of our faculty were no longer being charged to the Accounting Department. I have been aware of the situation since it began but it has not been corrected yet even though I have told members of the University in-house accounting department and the Administrative Services Vice-President who is over the accounting function. It has been suggested to me that I should have all of my faculty make all of their long distance charges on either of those two phones. With the amount of money I have stashed away in my "gift" account, I will certainly be able to pay the bill if and when the error is corrected. I feel that I have fulfilled my responsibility since I have made the in-house accountants aware of the situation.

\section{INTEREST EARNINGS}

Once I got the problem corrected in my scholarship account, I realized that there are certain accounts on which we are paid interest. Two of those accounts are the scholarship and the gift accounts. We had not been getting paid interest on the scholarship account because it had a deficit in it since 1993 and our gift account only had $\$ 1,768$ in it so we had not been earning much on that account. At the end of my first year as Department Chair, I realized that I had about \$20,000 left over and unspent. I transferred those funds into our gift account and was allowed to do so although in subsequent years I have not been allowed to do so as easily. I suppose the reason for that is that at the beginning of the next year when I received my approximately $\$ 40,000$ annual allocation, I tried to transfer the entire amount to the gift account in order to earn interest on the amount since interest is not paid on operating fund balances. That attempt caused massive heartburn in the administration and I was prevented from making the transfer. One of the main reasons given seemed to be legitimate in that even though I was allocated the $\$ 40,000$ budget at the beginning of the year, not all of those funds are received from the state at the beginning of the year. Still at every 
opportunity, I do transfer as much as possible from the operating fund to my gift account and by so doing have been able to earn almost $\$ 14,000$ in interest over the past six-and-a-half years.

Another source of interest income has been my scholarship account; the one the had a $\$ 3,500$ deficit when I began my tenure as chair. I have made a significant effort to increase the number of scholarships that we make available to our students. When I became chair, we awarded about five scholarships per year. We now award about twenty-five per year. We also do not award any scholarships for funds we have not yet collected. Scholarships are also never awarded in a single lump sum. They are awarded half each semester. Therefore, we always have a balance in our scholarship account. That account earns interest which is paid each quarter and when it is earned, I transfer the amount to our gift account. Therefore all scholarship contributions go directly to student recipients but any interest earned on those funds become discretionary income which help to allow me to increase our travel funds.

\section{DEPARTMENT ALLOCATION FROM THE DEAN'S OFFICE}

During the years 1997 to the present, at least, there has been no increase in operating funds received from the Dean's office either in terms of actual or inflated dollars.

\section{WHAT HAPPENED IN PRIOR YEARS}

I realize that a logical and legitimate question would be, "How could you have increased your travel funds by this amount without any increase of budget from the Dean's office?" My answer is, "I don't know and I am not going to find out." The prior chair is no longer with our faculty. Whatever happened to those funds in prior years whether it was simple mismanagement or even misuse makes no difference to me. Even if I were to find that it was misuse, there is nothing I can do about it at this point in time.

It is interesting to note that the prior Department chair resigned right in the middle of a three-year appointment. Just prior to her resignation, she informed the department faculty that we were probably going to have to reduce our allocated travel from $\$ 1,000$ per faculty to $\$ 800$ because of insufficient funds. "Travel" included professional dues, computer hardware and software, or any other professional expenses incurred by the faculty member.

In the past six years, the "travel" budget has been as indicated above. The total for the seven years from 1998 to 2005 is $\$ 322,780$. At $\$ 11,000$ per year, which our travel had been for the prior years, that is an increase of $\$ 234,780$. During that same time period, our slush fund has increased over $\$ 133,000$. How could this occur? I don't know and I am not going to find out. I do know, however, where every penny has been spent during the past six-anda-half years.

\section{MIS-CODED EXPENSES}

As I say, I don't know what happened to the department funds in the years prior to July 1, 1998. However, I must assume that many of those funds were misapplied by the University accounting function and never corrected. Over the past years, it has been more common for me to find expenses charged to the Accounting Department which are not ours than to find all expenses properly charged. One month, I found over $\$ 1,000$ that was charged to our account that should have been charged to the Management Department. I had that corrected the following month.

In September of 2001, I found $\$ 380$ that was charged to us that was actually for a totally different department in another college. That one took two months to get corrected but it has now been corrected.

In summer, 2002, I found a scholarship distribution which should have come out of the MBA program. That one took a while to analyze and get corrected but it did get corrected. The list of errors could go on for many more pages of this paper but that does not seem necessary. 


\section{DIFFERENTIAL GRADUATE STUDENT TUITION}

We are a state university. There are ten institutions in our state system. We are probably the fifth largest in that system and one of four which have graduate programs. Apparently, at the flagship institution, a differential graduate tuition was instituted of $\$ 40$ per credit hour. When that was done, apparently the state legislature insisted that all state institutions institute the same charge. For some reason, and with no input from our faculty, that differential tuition is allocated directly to the department from which those students come. Since 2001, we have received about $\$ 30,000$ per year from this source. Assuming that this funding continues into the future, it appears that there will be no problem maintaining travel funding at least at the current level.

\section{ALLOCATING “TRAVEL” FUNDS FOR MANAGEMENT PURPOSES}

About a year after I became Department Chair, the Dean requested that I get resumes from each of my faculty. That seemed like a simple task so I asked each of them for a copy of their current resume. It took me months to get the final resume from those ten other faculty members. I could not believe how difficult it was to get current resumes from faculty. I guess I was just a naive new Department Chair.

Early in 1999, the AACSB proposed some new accreditation criteria for Accounting Department accreditation. Those two criteria were Continuing Education and Professional Interaction. After my resume collection experience, I could not see how I would ever get that information from this faculty. Therefore, I devised a way to get the information while at the same time rewarding productive faculty for their efforts.

At the same time that I was faced with the task of getting continuing education and professional interaction information, I wanted to encourage faculty support of Beta Alpha Psi students, encourage academic scholarship, increase professional involvement, reward service, and encourage effective teaching. Therefore, about two-thirds of this year's $\$ 62,080$ of travel funds are allocated on a performance basis. The following table shows the allocation of the $\$ 62,080$ current year "travel" funds.

\begin{tabular}{|c|c|}
\hline Scholarship & $\$ 9,000$ \\
\hline Service & $\$ 3,500$ \\
\hline Teaching & $\$ 8,000$ \\
\hline BAP Book Exchange & $\$ 880$ \\
\hline BAP Attendance & $\$ 4,000$ \\
\hline Continuing Education & $\$ 3,500$ \\
\hline Professional Interaction & $\$ 3,500$ \\
\hline Graduation Attendance & $\$ 2,200$ \\
\hline TOTAL & $\mathbf{6 2 2 , 5 8 0}$ \\
\hline
\end{tabular}

\section{SUFFICIENCY OF TRAVEL FUNDS}

In recent years, most of our faculty have not spent all of their travel funds by the end of each academic year. They have been allowed to carry over those funds into the following year. I have seldom had faculty come to me asking for travel support on an individual basis. Apparently, the level of travel support that we now have has been sufficient for all faculty.

\section{SIMPLICITY OF USING DEPARTMENT FUNDS}

Allocating travel funds at this level has made my job as department chair infinitely easier than I imagined it would be. I have never been faced with a decision as to which faculty member's travel or other expenditure to fund and which to reject. I am almost never even informed by faculty of their travel plans. 
Any individual expenses that faculty want to incur are taken from their own travel accounts so as department chair I am not making decisions regarding minor expenditures. For example, one faculty wanted to use a personality profile in one of his classes. The cost was about $\$ 140$. He did not even tell me of his plans and certainly did not ask permission. Another faculty wanted to purchase a book. In this case the faculty did approach me and ask for funding. I simply told him that I allocate as much of the department funds as possible to them individually so he would have to do that from his own travel funds. That seemed to satisfy him and I never heard more about it. I even have had some faculty members purchase new computers and the first I heard about it was when I was asked to sign the purchase requisition.

By reducing my involvement in insignificant faculty activities, I have been able to concentrate my own efforts on fund raising, professional involvement of my own, and my own research. During the past six-and-a-half years, I have published thirty-three articles.

\section{THE SUCCESS OF THE ALLOCATIONS MODEL}

Professional meeting attendance and professional dues are now paid separately from individual travel accounts. My goal was to increase the professional involvement of our faculty. This has been marginally successful. However, it has succeeded in rewarding those faculty who are professionally involved by making it so they do not have to pay for that professional involvement from their own accounts. It seems to have been more successful in encouraging membership in professional organizations.

Two things about graduation have always bothered me. One was that so few faculty bother to attend graduation exercises and the other was that we made faculty pay for rental of the cap and gown out of their own pockets. To encourage graduation attendance by our faculty, I now allocate $\$ 100$ for graduation at both the winter and the spring graduation exercises. The faculty may use those funds to pay for rental of the cap and gown which costs about $\$ 40$ or simply use it for travel if they own their own cap and gown. "Travel" funds can be used for any legitimate academic purpose so they could even use those funds to purchase their own regalia.

Because funds are allocated based on the level of continuing education, professional interaction, scholarship, service, teaching, graduation attendance, and Beta Alpha Psi participation, I have to believe that the level of this faculty's activity has increased. If it has not increased, at least I take comfort in the knowledge that those who are more involved in these areas are being rewarded at a level above those who are not thus involved.

I am a strong supporter of Beta Alpha Psi and felt badly that we were not getting what I considered adequate faculty attendance at those meetings and activities. Therefore, I allocated $\$ 4,000$ for BAP attendance. That is allocated on the basis of $\$ 25$ per faculty per meeting. However, any unallocated funds at the end of the year are allocated based on each faculty member's attendance to the total of all faculty attendance. Therefore the entire $\$ 4,000$ is allocated each year regardless of the level of faculty attendance. We typically get 5-8 faculty at each Beta Alpha Psi function so it appears that this approach has increased faculty attendance at BAP meetings but even if it has not increased attendance, it certainly does reward those who do attend more than those who do not. Beta Alpha Psi administers the campus book exchange and through that means generates most of their operating funds. For faculty who spend at least an hour at that book exchange, they are awarded $\$ 40$ of additional travel funds. The book exchange is conducted both autumn and spring semesters.

Continuing education, professional interaction, scholarship, and service funds are awarded on the basis of activity in those areas. The most any single faculty may receive in each area is $20 \%$ of the total available. This is an approach to spread the money among all faculty. Teaching is awarded to only the top eight teaching faculty based on student evaluations. The top teacher receives $\$ 1,800$ and the amount reduces such that number eight receives $\$ 200$.

\section{GETTING THOSE DARN RESUMES FROM FACULTY}

By January $31^{\text {st }}$ of each year, the faculty are required to submit to me a record of their continuing education, professional interaction, scholarship and service. If they fail to get me that information by January $31^{\text {st }}$, they forfeit 
their eligibility for additional travel funds. I have never yet had any faculty miss the January $31^{\text {st }}$ deadline. Along with the above information, they must also submit a current resume to be eligible for these funds. It now no longer take months to collect current resumes from my faculty.

\section{CONCLUSION}

I had no desire to become a Department Chair because I don't enjoy administrative activities and especially do not enjoy them in an academic setting. However, by the above approach to dealing with department funds, I have significantly reduced my involvement in what I consider a mundane activity. It has made my enjoyment level increase significantly. I can actually say that I have enjoyed being the Department Chair.

\section{NOTES}

